Assist. Prof. Boža Grafenauer, PhD,

Vocational College for Hospitality, Wellness and Tourism Bled,

boza.grafenauer@vgs-bled.si

Assist. Prof. Lea Kužnik, PhD,

Biotechnical Educational Centre Ljubljana, Vocational College.

lea.kuznik@gmail.com

DOI 10.5937/turpos0-33987

UDK 338.48-6:615.83(497.4)

\title{
NATURAL HEALING METHODS AS THE BASIS FOR THE DEVELOPMENT OF PREVENTATIVE WELLNESS PROGRAMMES - ARNOLD RIKLI'S POTENTIAL
}

\author{
METODE NATUROPATIJE KAO OSNOVA ZA RAZVOJ PREVENTIVNIH \\ WELLNESS PROGRAMA - POTENCIJAL ZA METODE ARNOLDA RIKLIJA
}

\begin{abstract}
This paper deals with the methods of natural healing that were practiced already in the 19th century by Swiss natural healer Arnold Rikli as a part of healing offer in Bled, Slovenia. The paper starts with the introduction of Rikli as a natural healer and his healing methods, based on hydrotherapy, heliotherapy, climate therapy and healthy diet. His healing methods were based on strengthening the immune system in a natural way. The paper takes an ethnographic approach based on in-depth analysis of the literature and online resources and fieldwork in Bled using the technique of partially structured interviews with the employees in tourist industry. The paper identifies the potential for the inclusion of Riklis natural healing methods in the modern tourist offer as the basis for creating Covid-adapted programmes and a source of survival for the existing wellness centres and other tourism providers in Bled.
\end{abstract}

Key words: Rikli, natural healing methods, tourism, Bled, Slovenia
Apstrakt: Ovaj rad obrađuje metode naturopatije koje je već u 19. veku primenjivao švajcarski naturopata Arnold Rikli, kao deo ponude lečenja na Bledu u Sloveniji. Rad počinje predstavljanjem Riklija kao naturopate $i$ njegovih metoda lečenja, zasnovanih na hidroterapiji, helioterapiji, klimatskoj terapiji i zdravoj ishrani. Njegove metode lečenja su se bazirale na jačanju imunološkog sistema na prirodan način. $U$ radu se koristi etnografski pristup zasnovan na dubinskoj analizi literature i elektronskih izvora, kao i terenski rad na Bledu u vidu delimično strukturiranih razgovora sa zaposlenima u turizmu. Rad identifikuje potencijal uključivanja Riklijevih prirodnih metoda lečenja u savremenu turističku ponudu, kao osnovu za stvaranje programa prilagođenih epidemiji COVID-19 $i$ kao izvor preživljavanja postojećih wellness centara $i$ drugih pružaoca usluga turizma na Bledu.

Ključne reči: Rikli, metode naturopatije, turizam, Bled, Slovenija 


\section{Introduction}

Natural healer Arnold Rikli was active in Bled, one of the most famous tourist attractions of Slovenia. The lake, the island, the castle on a cliff and the view of the Triglav, the highest mountain in Slovenia, make Bled a truly amazing place. And so is its history. Many finds prove that it was an important settlement and pilgrimage already a long time ago. At the end of 19th century it became a very important winter and summer resort visited by lots of significant guests, presidents, diplomats and cultural workers, also because of Arnold Rikli. Arnold Rikli was the first to recognise the natural attractions of Bled and started the so-called natural tourism, based on healing with natural methods and elements, such as water, air and light. Rikli used to customize the healing methods to each individual and his reputation was soon spread widely across Europe. Bled started to attract tourists from all over Europe. These were the beginnings of natural and preventive forms of healing as a part of tourism in Bled.

Due to Riklis successful healing with the effects of the sun, light and water, in the 19th century Arnold Rikli was called also sun doctor, the advocate of light, magic healer ... (Zavodnik, 2018). He himself used the methods that he recommended to his patients because as a young man he healed himself with the help of hydrotherapy. Therefore, it is sensible to call Rikli the pioneer of a later development of spa and wellness tourism not only in Bled, where he was living and working, but also in the entire country of Slovenia.

However, healing with the help of water is not something new as people have always believed in the healing and magic power of water. It was particularly important to wash oneself with spring water on the New Year's Day as it has a special healing power on that day.

The main purpose of this research is to explore the current situation related to spa/ natural tourism in Bled, and to explore Riklis natural healing methods and their potential for possible inclusion in a new Covid tourist offer based on long wellness tradition in Bled.

The main goal of the research is to identify and describe various Riklis natural healing methods which are not included (very well) in current spa and wider tourist offer in Bled. Rikli's natural healing methods offer a variety of new opportunities for the improvement in developing spa/natural tourism in Bled.

Rikli's heritage in Bled, especially his healing methods, is an opportunity and basis for the creation of a new Covid-adapted tourist offer, based on new preventive, authentic, sustainable and personalised tourist products in harmony with the natural resources of Bled.

\section{Natural and folk healing heritage}

First written records about the natural healing in Slovenia date back to the 17th century (Moderndorfer, 1964). The term natural healing encompasses the way of healing internal and external illnesses in humans and animals in folk healing and healing of animals. Medications of plant and animal origins were prevailing, as well as inanimate substances such as water and soil. Plant-based medications were prepared as tea, syrup or tincture, and animal-based ones as ointments. In addition, heritage knows also healing by placing hot stones on the affected part of the body, spilling over with water, mud wrapping... (Baš, 2004, p.289). Natural healing was simple and not professional, sometimes magic words and curses were used as well.

One of the ways of natural healing was also healing or washing with water. Such healing, with spring water, for example, helped in eye diseases, and healing with dew in skin diseases. Sometimes washing was accompanied by magic words. Washing with healing water was known all over Slovenia, and in some parts it is still pres- 
ent: Tunjice, Lurška jama v Zagorju, Bukovniško jezero...

Diets were also a part of folk healing, although different as also the food we eat today, is different. Certain nourishing dishes were recommended, such as chicken meat and soup, eggs, prežganka (soup made by roasting and browning flour), white bread. As for the drinks, red wine was considered to be nourishing and healing (Židov, 2000, p.148).

Folk healing has been developing for centuries. Knowledge and experience are passed from generation to generation. In addition to various healing plants and herbs, also resin, wax, honey, wine, roots, crystals, minerals, metals, animal claws, horns, teeth, fat ... have been used.

Slovenian polyhistorian Janez Vajkard Valvasor wrote in his most extensive work The Glory of the Duchy of Carniola (1689), describing the way of life in the 17th century in the territory where we are living today: „Carniolan peasant will not give a lot of money to a doctor as most of them heal themselves and they know herbs very well. Several are very good healers and have excellent results in healing with resin and healing roots.“ (Valvasor, 1689).

Therefore, natural healing with the help of water, fresh air, exercising in nature and suitable diet are not an invention of modern times. The ideas about healing chronical illnesses with the help of natural methods came to Slovenia from Germany in the 19th century. Those methods were empirical and not proved scientifically. It was mostly laymen who were the founders of such methods, which were discovered more or less by accident, also with their own experience (Židov, 2000).

\section{Healer Arnold Rikli's heritage of nat- ural healing methods}

In Slovenia, the most popular were natural healing methods, established by German priest Sebastian Kneipp and Swiss factory owner Arnold Rikli. Both natural healers lived in the first half of the 19th century and were the first to popularize natural methods for general use. They both advocated for similar natural healing methods on the basis of natural resources and healthy diet, and due to their own ill health they were both testing the methods on themselves. Kneipp method was more popular among simple people, while only more well-off people could afford Rikli's method (Židov, 2000 and Borisov, 1968).

In spite of numerous similarities, Kneipp is very famous in Slovenia as well as abroad, his healing methods are still used. Unfortunately, Rikli's methods have never been recognised as an enormous potential for the development of modern tourism, not even in Bled, where he started to work, in spite of the fact that Rikli had been treating with water more than 3 years before Kneipp started his hydropathic tests (Zavodnik, 2018, p.10).

Arnold Rikli, born in 1823 to a rich Swiss family, had a lot of personal experience with natural healing. As a young man, he fell seriously ill and then got well with the help of hydrotherapy. It is not surprising that he became an enthusiastic hydropath. He had personal experience with natural healing also later as he had pleurisy and came to Bled to recover. He found the natural features and climate in Bled so fascinating that he decided to set up a natural healing centre there. In 1855 he moved to Bled, and two years later he developed a top European centre for recovering after illnesses and improving health: Natural Healing Institute for helio-hydrotherapy healing. His motto was: Water is good, air is better, and above all the light (Borisov, 1975, p. 173 In Židov 2000, p. 141,142). His methods were called atmospheric, based on the supposed healing effects of water, air and light (Židov, 2000, p. 141, 142).

He added diet to those methods, mainly vegetarian, and a lot of exercising. The 
aim of his healing was to prolong human life with healthy way of life and as few medications as possible. He was often arguing with doctors because he was opposing the use of medications that they were prescribing (Borisov, 1975, p. 171 in Židov 2000). Rikli was emphasising a personalised way of healing for each patient and holistic treatment and healing of patients (Zavodnik, 2018). In that way he was healing various conditions such as rheumatism, hysteria, migraine, insomnia, anaemia... (Žemva, 2004).

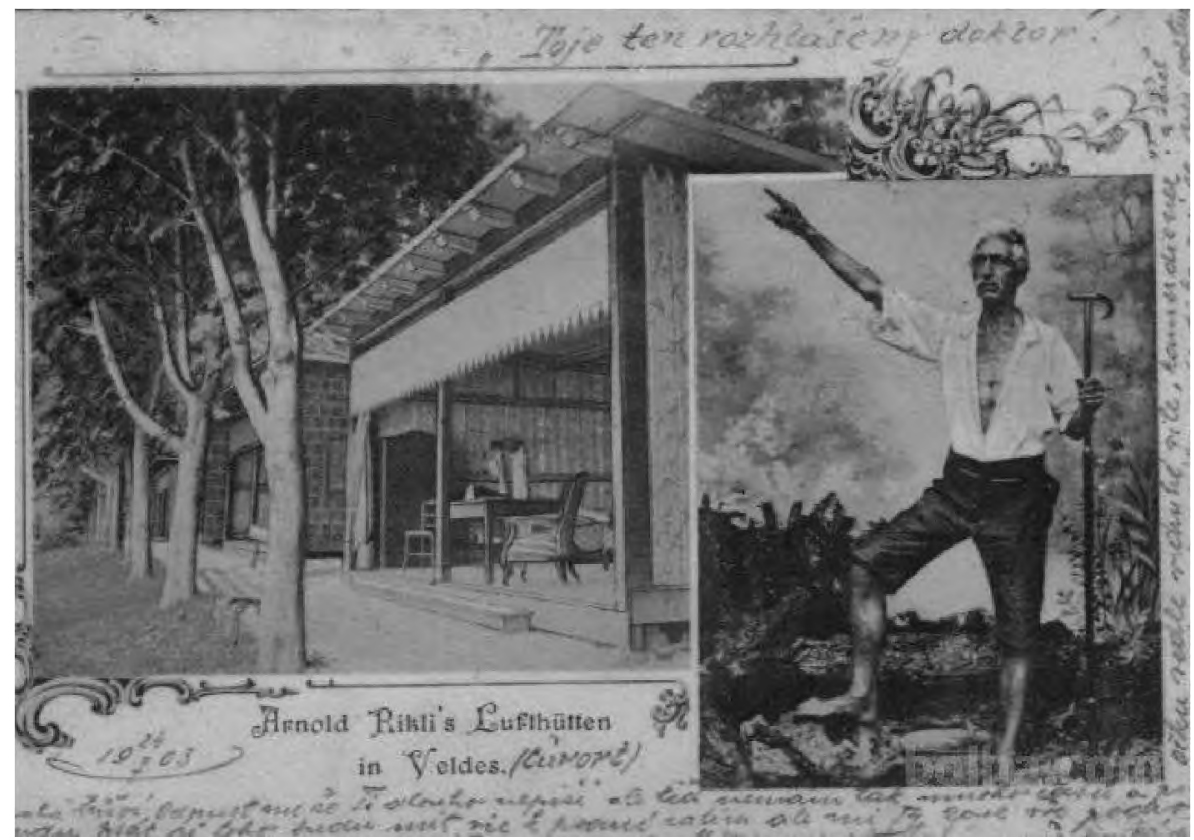

Fig. 1 Postcard. Portrait of Rikli, pioneer of natural tourism in Bled in front of Rikli special airy wooden huts forpatients (http://zgodovina.si/zacetnik-modernega-turizma-in-zdraviliskega-delovanja-na-bledu/)

His therapies included warming and cooling of the body with air, light and sun baths, steam baths, dry and wet wrapping in sheets, rubbing with a towel, soaking in cold water, various cold and hot wraps and baths, also by sinking the whole body, sprinkling and showering. Therapies were conducted in groups, which was easier for the patients who were a bit frightened at the beginning.

Exercising was an important part of healing. He selected numerous walking paths of different levels of difficulty in the surrounding of Bled. He recommended his patients to walk barefoot as much as possible. They were wearing special shirts and living in airy wooden huts with curtains, which was very innovative for those times. Their diets were customised for each individual patient, and it included drinking large amounts of water.
For breakfast, they had bread with cold or hot sweetened or sour milk, porridge, honey, fruit jelly, and coffee substitute, made of figs, barley or acorns. Dinner was simple with a lot of fruit. (Zavodnik, 2018, p. 118). Rikli was buying all the ingredients for healthy meals from the local farmers.

Rikli's daily therapies were based on vegetarian food, sun, air and water baths and exercising. His patients had a very strict daily routine. They had to get up early, ate meals without meat, smoking and drinking alcohol was prohibited. That was followed by individually prescribed therapies, based on the alternative use of hot and cold water (baths), aimed at strengthening the body. After the baths, patients were sunbathing naked, which was another Rikli's innovative idea, considered very bold and outrageous in 
those times. After that, it was compulsory to exercise outside, in nature. Each patient had their own, very strict programme of healing. Those who did not stick to it, had to leave the Institute immediately (Zavodnik, 2018.).

Rikli described his healing as follows: „Healing in Bled is not a 'sine-cure', simple. It is completely different from those who spend their time in thermal spas, where people usually overeat, lie around and sleep too much. In Bled, patients have to work hard for their health. They do not become fat and lazy, but gain their muscle mass, become resistant to seasonal fluctuations and thus reduce the effects of illnesses. And while their bodies are getting healthier and stronger, also their mind (reasoning) is becoming more light-hearted, energetic and decisive. What seems to be a difficult task on the outside, soon becomes the source of enjoyment and joy." (Rikli, 1881 In Zavodnik 2018).

His healing was successful due to strict following of healthy life style on everyday basis. He respected the nature, believed in its almighty power and therefore he was submitting to the laws of nature without compromise.

The healing, based on natural elements, sun, water and air, lasted for at least one month. As it was very expensive, only the richest could afford it. The number of patients was high and two doctors hydropaths were helping in Rikli's natural healing institute. Rikli founded some similar institutes also in Trieste, Florence and Merano. Natural healing institute in Bled stopped its operation after the First World War (Borisov, 1975 in Židov 2000).

\section{The research}

The paper aims at analysing the significance of Rikli and his healing methods, representing the beginning of the preventative wellnesstourism development in Bled, and at assessing and presenting the potential for the inclusion of his healing methods in the contemporary Covid tourist offer of Bled, which must be highly individualized and personalized.

The research presented here is an exploratory study based on a multi-method approach including studying literature and online resources and semi-structured interviews (personal communication) with the employees in tourist industry in Bled, mainly in wellness centres and hotels. In doing so, we wanted to find out to what extent they include preventive treatment programs based on Rikli's heritage in their modern wellness and wider tourist offer and in what way.

The main research question is as follows: In what ways hotels, inns, wellnesses and sports agencies in Bled include the elements of Rikli's natural healing methods and his forms of healing, based on prevention, into the modern tourist offer?

To find out we first analysed the literature and existing documentation (old newspapers articles, photographs) and web sites of hotels, inns, wellnesses and sports agencies in Bled. On the basis of the collected material and analysis thereof, assessment and potential of Rikli's natural healing methods for the inclusion in the new Covid tourist offer, will be made.

Rikli's heritage in Bled is way underutilized with enormous opportunities for the creation of the so-called Covid tourist offer, based on new authentic, sustainable and personalised tourist products in harmony with the natural resources of Bled.

\section{Rikli's heritage in today's tourist offer of Bled}

Arnold Rikli's heritage in Bled is shown in various elements. Mostly, it refers to preserving his material heritage and pointing out Rikli as a historical person, important for Bled, while it is not possible to experience his essence - natural healing methods and his entire philosophy of healing. The 
ambivalent attitude to his personality and work has not changed much since the 19th century, when Rikli lived in Bled.

Numerous ,sights" in Bled have been or are named after Rikli, including some accommodation facilities and dishes, offered in Bled restaurants, such as a pizza with salami or suckling pig, which is contrary to Rikli's philosophy about healthy diet as the basis for well-being (Mlakar, 2019).

Quite a substantial part of Rikli's material heritage, such as his depictions, pictures, plaques, and two monuments. The monument on Straža was erected 1905 on the 50th anniversary of Rikli's activity in Bled, while the monument in Spa Park was erected by Tourist Society Bled on the 125th anniversary of the Park. A street and two residential villas also bear Rikli's name.

In the museum in Bled Castle, there is an exhibition about Rikli and Rikli's room, opened to celebrate 160 years since Rikli's arrival to Bled (Zavodnik, 2018).

A documentary entitled Arnold Rikli water, air, sun was made, directed by Amalija Jelen Mikša, winning the first prize at the 9th international tourist festival in Portugal in 2016 in category biographies, and a special reward at the 20th international ITF-
CRO Tourfiolm Festival in Thessaloniki in 2017 (Zavodnik. 2018, p. 335).

One of the biggest disgraces of Rikli's heritage is the dilapidating Rikli's Villa, built in Swiss style, where Bled tourism started. Due to numerous complications regarding the ownership, the Villa is still waiting for renovation.

This means that there are quite a few preserved elements of Rikli's heritage in the sense of museum presentation, monuments and various depictions. However, the essential element - Rikli's philosophy of natural healing with his healing methods based on water, air, sun, exercising and healthy food - has been neglected.

In the today's tourist offer programmes on that basis are rare. Every first Sunday in July Tourist Society Bled organises Rikli's hike along Rikli's path to Straža, where Rikli was taking his patients. The programme includes breakfast on Straža, air, sun and water baths and lunch on a meadow by the lake. According to Rikli's philosophy, it is recommended to walk barefoot and wear light clothes and straw hats. Every Tuesday in July and August morning walks to Straža are organised - Barefoot along the morning dew (Riklijev pohod 2019).

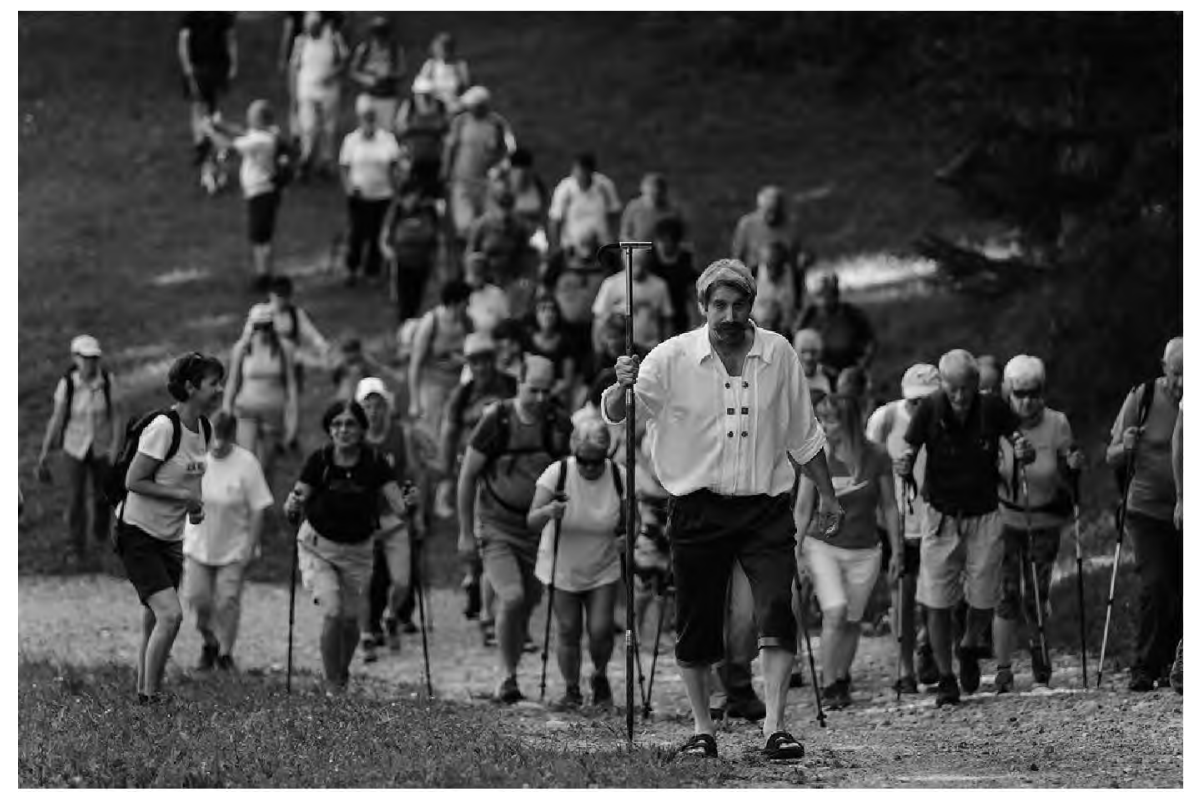

Fig 2. Rikli's hike to Straža Hill, 2019

(https://www.mojaobcina.si/bled/novice/riklijev-pohod.html) 
It is only one hotel in Bled, the Golf Hotel, renamed during the last renovation to the Rikli Balance Hotel and housing Wellness Centre Živa, that includes Rikli's philosophy and his healing methods in their offer. The concept of the hotel is based on healthy lifestyle and they offer also regeneration Rikli's rooms, furnished in natural materials such as wood and wool, where one of the alternative medicine methods is carried out - chromotherapy or therapy with colours with red, white, blue and green light. Walls in Rikli's regeneration rooms are covered in moss which clears bacteria from the air and contributes to the holistic renovation of the body and mind.

Wellness Centre Živa offers Rikli's Day Ritual and Rikli's bath. Rikli's Day Ritual is a programme for relaxation and regeneration of the body and includes saunas with pools, herbal peeling, massage with bunches of spruce tree shoots, and a healthy drink in the relaxation room. An emulsion at your choice is mixed in Rikli's bath.

There is a Rikli relaxation park in front of the hotel, offering barefoot walks, hugging of tress and special work-out(Bogata zapuščina Arnolda Riklija 2021).

Hospitality and tourism study programmes at the Vocational College for Hospitality, Wellness and Tourism also include Rikli's heritage, which is included also in study projects, planned for up-to-date tourism.

Jörg Wolff Foundation, established as a non-profit foundation in 2004, recognised Rikli's significance beyond Slovenia. Every year, they award Arnold Rikli award, aimed at all scientific disciplines, represented in photobiology at an international level, dealing with the effects of optical radiation on human organism. Arnold Rikli award is given to a scientific work, dealing with that topic(Der Arnold Rikli Preis, 2020).

\section{Discussion of results}

Nowadays, a general European tourist trend is to build on recognition and tourist products on the basis of positive and tested practices and stories from our heritage. With its recipes, which have been tested here several times, heritage is an excellent basis for building authenticity in accordance with natural conditions and opportunities. Revival of Rikli's methods can be an excellent example of linking local heritage of natural healing with new, up-to-date interpretations. Due to their efficiency and accessibility, Rikli's methods are more than relevant also today. Going back to nature, life in connection with nature and efforts for prevention of illnesses are the right guidelines at any time, and particularly in the Covid times we are experiencing.

Unfortunately, Rikli's name and heritage have never been a part of the comprehensive development of Bled, which is one of the most popular tourist destinations in Slovenia. Up to date, only individual efforts by enthusiastic individuals and some talented profit-makers have been noticed. The reason for partial and careless trials of marketing Rikli's doctrine in Bled is the ignorance about Rikli's significance, not knowing what had actually happened, and key characteristics of Rikli's life and his atmospheric healing. A renewed comprehensive and transparent offer of Rikli experience can be built only on professional grounds and with the right basis, adapted to modern times, of course (Završnik, 2018 in Zavodnik 2018, p. 364).

Undoubtedly, the following question arises: How can Rikli's natural healing methods and his forms of healing, based on prevention, be included in the new Covid tourist offer? Can the new programmes, based on Rikli's methods, represent or replace the programmes by classical wellness centres with the wellness preventive programmes? Rikli's natural healing methods 
are an opportunity and should be basis for the creation of a new, Covid-adapted tourist offer, based on new preventive, authentic, sustainable and personalised tourist programmes in harmony with the natural resources of Bled.

Modern way of life is characterised by unhealthy lifestyle, lack of physical exercise, too much unhealthy food and constant stress. In case it lasts for too long and we are not able to manage it, it can lead to burn-out which is one of the most common terms used when describing theproblems of modern times. The line between leisure and work time is more and more blurred. Therefore, preventive programmes are extremely important.

Comparison of the wellness offer in connection with Rikli and his healing in the past shows that the main difference is in the approach and understanding healthy way of life that Rikli understood as a long-term project which requires hard work in order to achieve the objective. As he himself was emphasizing, his healing was not sine cure, simple. According to his philosophy, up-todate instant programmes do not bring health and healthy life.

Also reasons for going to wellness centres and duration of healing are different. Rikli's patients were staying for at least a month so that they internalised a healthy way of life while nowadays people stay in wellness centres only for a short period of time, in best case for a week. In the Rikli Balance Hotel ,live according to Rikli“" perceive as a short programme which includes certain elements of Rikli's healing, getting up before sunrise, drinking fresh Bled water before breakfast, barefoot walking on the meadow on morning dew, light meals, swimming, sunbathing and exercising outside in fresh Alpine air (Bogata zapuščina Arnolda Riklija 2021).

As long as 160 years ago, Rikli was promoting healthy way of life and great respect for nature. It required a high level of responsibility for one's own health. He encouraged quality spending of free time, music, dancing, enjoying the views... He emphasised a holistic approach to healing and individualised healing, customized for each patient. Nowadays, wellness centres and spas are visited by various groups of people who seek relaxation while Rikli's healing institute was visited by patients who were exhausted and weak and needed health care.

The current health situation in the world with Covid epidemic shows what an important value health is. This preventive and curative context could include also Rikli's natural healing methods in Bled, which could serve as the basis for planning preventive, curative, authentic, sustainable and personalised tourist products and programmes, based on the natural resources of Bled.

However, the inclusion of Rikli's natural healing methods and his efforts to modern tourist offer has to be done in a comprehensive way. Real perception of Rikli's philosophy does not mean only individual techniques within methods but a comprehensive system of natural methods, aimed at prevention, healthy and quality way of life.

In the context of tourism, Rikli's philosophy should become an umbrella story for Bled, as it is based on all the guidelines and highlights, included in the Strategy for Sustainable Growth of Slovenian Tourism, where Slovenia is positioned as a green, active and healthy destination for 5-star experiences. Natural resources of Bled comply with all those highlights, connecting activities or exercising in connection with health, which finally leads to a 5-star experience (Priročnik Slovenia Unique Experiences, 2020).

Rikli's philosophy of natural healing can be included in tourist offer at two levels: Bled as a tourist destination which promotes a healthy way of life in the sense of a collective brand name, and at the second, higher level Rikli as a promoter of healthy way of life or Rikli as a product, which includes 
also different healing, preventive tourist programmesin wellness centres which consistently follow Rikli's doctrine and are connected in a sensible way. All products have to base on the natural elements - sun, water and air.

The significance and value of Rikli's traditional knowledge and practice could be confirmed by entry in the national register of intangible cultural heritage. At the moment, the list includes only the elements of immovable local cultural heritage of Bled, connected with Rikli - ruins which used to be Rikli's healing institute and Rikli's monuments on Straža and in the Spa Park (Register nepremične kulturne dediščine, 2021).

Rikli's philosophy of healing could be transferred into everyday practice also within various associations, societies and schools, which would continue his knowledge and practice with educational programmes, conducted by natural healing experts, and including Rikli's methods in spa and wellness tourism and publishing their findings in scientific literature.

13th February, Rikli's birthday, could be celebrated by festivals, events, days of health and various events. Year 2023 could be celebrated as Rikli's year as it will be 200 years since his birth.Rikli's heritage could be also a good business opportunity for several companies which would build their competitiveness on Arnold Rikli's naturopathic heritage.

And last but not least, Bled, a place where Arnold Rikli was operating, could also include Kneipp's heritage and promote itself as Rikli's place, where guests can experience Rikli's therapy at the original place and in the most original way as possible.

Rikli himself could be a good model for contemporary promotion and marketing of the brand as he created a successful business model already at the end of the 19th century. He believed in his work, before launching it to the market, he tested each natural healing method on himself, he studied po- tential patients' needs and created suitable programmes. He invested only in what he believed would be effective, the natural resources he was using were free of charge as was the first treatment for each individual patient. He had a clear vision and strategy how to put it into practice. He created an excellent slogan and logo. He was building public relations with simple advertising, reports and articles and thus reached all market segments. He was constantly supplying the market by brochures, leaflets, books, and manuals. Positive public relations were built also by court proceedings that he was winning and received a lot of attention, while he responded to business sullying and blaming by diplomatic responses. He was following the newest trends in natural healing, evaluating his methods, critically correcting his mistakes and analysing the growing competition, and also acting against non-loyal imitators. The drive for growth was his trust in the future. He was employing mainly local people and invested in their training.

His offer of healing services was appropriately defined for various target groups of patients and their economic abilities and level of obesity. He was active also at the global level and opened the subsidiaries of natural healing institutes also in Ljubljana, Trieste, Florence, Merano and Gries (Zavodnik, 2018, p. 197, 198).

\section{Conclusion}

Today, Bled still represents one of Slovenia's main tourist attractions. Arnold Rikli is one of the pioneers of tourism, offering food and accommodation as well as his healing methods and its non-exploitation is a black dot of Bled tourism. More than 160 years ago, in Bled Rikli set up the foundation which is nowadays the basis of the entire Strategy for Sustainable Growth ofSlovenian Tourism, defining Slovenia as a green, active and healthy destination for 5-star experiences. 
He was advocating for strengthening the immune system in a natural way. His healing was based on atmospheric healing with the sun, water and air, and complemented with mainly vegetarian diet and a lot of exercising. In his opinion, achievement of the set objectives and being moderate in all fields are also important for well-being. His methods are extremely relevant also nowadays, only different terms are used.

Arnold Rikli is an essential distinctive element for Bled which makes Bled different from all other similar (wellness) destinations in Slovenia. His name can be a reliable brand name, based on his natural healing methods, adapted for the modern times. Nowadays, natural healing methods with the help of water, fresh air, exercising in nature and healthy diet are called prevention and they are present in all wellness centres.

Arnold Rikli's heritage is fragmented as is its inclusion in modern tourism in Bled. Furthermore, individual elements of his heritage are often excluded from a wider context. Real perception of Rikli's philosophy does not mean only Rikli as a historic personality, important for Bled, or individual techniques within his special healing methods but a comprehensive system of natural methods, aimed at prevention, healthy and quality way of life and as such, due to the significance and relevance, a great potential in the field of preventive and wellness programmes in Bled.

First, Rikli's natural healing methods have to be recognised and evaluated and then up-to-date interpretations of natural healing for modern times created on that basis. Natural healer Sebastian Kneipp can be taken as an example of good practice.

The rediscovery and inclusion of Riklis healing methods in the tourist offer may be very relevant in these Covid times, as the healing can be carried out in spite of numerous limitations. At the same time, it can be the basis for creating Covid-adapted programmes and a source of survival for the existing wellness centres.

A suitable combination of individual elements of the heritage could result in an excellent product that would enrich and upgrade current Bled tourist offer.

Rikli's heritage in Bled is an opportunity and basis for creating new, authentic, sustainable, personalised, 5-star preventive wellness programmes in harmony with the natural resources, offered in Bled in accordance with the strategy of sustainable growth of Slovenian tourism.

\section{References}

Baš, A. (Ed.) (2004). Slovenski etnološki leksikon. Ljubljana: Mladinska knjiga.

Benedik, B. (1993).Bled, ta naš Bled! Ljubljana: Eurodesign.

Benedik, B. (2003).Bled nekoč in danes. Bled: Višja strokovna šola za gostinstvo in turizem.

Bogata zapuščina Arnolda Riklija. (2021). Retrived December 12, 2020 from https://www.sava-hotels-resorts.com/ si/sava-hoteli-bled/dozivetja/bogata-zapuscina-arnolda-riklija.

Borisov, P. (1975). Sto dvajset let od ustanovitve naravnega zdravilnega zavoda na Bledu. V: Zbornik za zgodovino naravoslovja in tehnike. Ljubljana: Slovenska matica, pp. 159-174.

Borisov, P. (1985).Zgodovina medicine. Ljubljana: Cankarjeva založba.

Borisov, P. (1968). Zdravilišča in kopališča na nekdanjem Kranjskem. In: Kronika 16,pp. 45-58.

Der Arnold Rikli - Preis. (2020). Retrived December 9, 2020 from https://www.joerg-wolff-stiftung.de/forschungsfoerderung/der-arnold-rikli-preis/.

Mlakar, P. (2019). Dva kilograma resnic o Arnoldu Rikliju, začetniku zdravilstva na Bledu. Dnevnik. Retrived December 
9, 2021 from https://www.dnevnik. si/1042874552/lokalno/gorenjska/ dva-kilograma-resnic-o-arnoldu-rikliju-zacetniku-zdravilstva-na-bledu.

Möderndorfer, V. (1964). Ljudska medicina pri Slovencih $=$ Volksmedizin bei den Slowenen. Ljubljana: Slovenska akademija znanosti in umetnosti.

Priročnik Slovenia Unique Experiences. (2020). Retrived December 12, 2020 from https://www.slovenia.info/uploads/5_zvezdicna_dozivetja/prirocnik sue_-_november_2020_dopolnitev.pdf.

Register nepremične kulturne dediščine. (2021). Retrived January 3, 2021 from

(http://giskd2s.situla.org/rkd/Opis.as$\mathrm{p}$ ?Esd=13181).

Riklijev pohod. (2019). Retrived December 12, 2020 from https://www.mojaobcina. si/bled/novice/riklijev-pohod.html.
Strategija trajnostnega razvoja blejskega turizma 2018-2025. (2018). Retrived January 9, 2021 from https://www.e-bled.si/wp-content/ uploads/2019/04/Strategija-trajnostnega-razvoja-blejskega-turizma-2018-2025-6.pdf.

Valvasor, J.V. (1978). Slava vojvodine Kranjske. Ljubljana: Mladinska knjiga.

Zavodnik, V. (2018). Po sledeh Arnolda Riklija. Bled: Zavod za kulturo.

Židov, N. (2000). Ali so metode alternativne medicine v Sloveniji res nekaj povsem novega? In: Etnolog, Vol. 10, pp. 139-159.

Žemva, A. (2004). Sebastian Kneipp in Arnold Rikli danes. In: Za srce. Vol. 13, No. 6, pp. 12-13. 